\title{
The choral song for the integral training of students in Nursing
}

\section{El canto coral para la formación integral de los estudiantes en Enfermería}

\author{
OSA-RICARDO, Arlena ${ }^{1} \dagger^{*}$, JONES-SÁNCHEZ, Elisneisis ${ }^{2}$, RODRÍGUEZ-JUAN, Arién ${ }^{3}$ and \\ BARREIROS-LÓPEZ, Silvia Elisa ${ }^{2}$
}

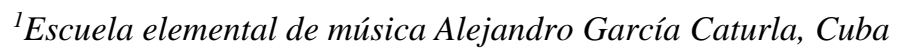

${ }^{2}$ Universidad de Ciencias Médicas, Facultad 10 de octubre, Cuba

${ }^{3}$ Universidad Autónoma de Zacatecas, México

ID $1^{\text {st }}$ Author: Arlena, Osa-Ricardo / ORC ID: 0000-0002-2280-0127

ID $1^{\text {st }}$ Co-author: Elisneisis Jones-Sánchez / ORC ID: 0000-0003-0873-9996

ID $2^{\text {nd }}$ Co-author: Arién, Rodríguez-Juan / ORC ID: 0000-0003-4923-7431, CVU CONACYT ID: 566873

ID $3^{\text {rd }}$ Co-author: Silvia Elisa, Barreiros-López / ORC ID: 0000-0003-4071-8343

DOI: $10.35429 / J E T .2021 .14 .5 .10 .20$

Received July 14, 2021; Accepted December 29, 2021

\begin{abstract}
This research constitutes a response to the current need to contribute to the comprehensive training of students of the Higher Education Level of Short Cycle in Nursing with the use of choral singing, where the study of the theoretical referents of choral singing is outlined. in contribution to the comprehensive training of Nursing students. For its development, singing skills are necessary, technicalmusical procedures and elements are used that favor the formation of human values and an aesthetic attitude, which are subsequently applied to other contexts, on the platform of ethics that this discipline requires. In addition, it allows to express the accumulated historical-social experience, based on feelings, emotions, moods and experiences. This is a way of realization that intertwines its implementation with technical-training elements. Research methods were used for the theoretical and methodological study with international and national authors in relation to the subject in question, which allowed the assumption of scientific positions, supported by systematized references, as a significant contribution that is reversed in practice, with social and social relevance. Scientific novelty, which makes it relevant within the Professional Training Model of the Short Cycle Higher Education Level in Nursing.
\end{abstract}

Choral singing, Comprehensive training, Nursin

\begin{abstract}
Resumen
Esta investigación constituye una respuesta a la necesidad actual de contribuir a la formación integral de los estudiantes del Nivel de Educación Superior de Ciclo Corto en Enfermería con el empleo del canto coral, donde se traza como objetivo el estudio de los referentes teóricos, del canto coral en contribución a la formación integral de los estudiantes de Enfermería. Para su desarrollo es necesario habilidades para el canto, se emplean procedimientos y elementos técnico-musicales que favorecen la formación de valores humanos y una actitud estética, que se aplican posteriormente a otros contextos, sobre la plataforma de la ética que exige esta disciplina. Además, permite expresar la experiencia histórico-social acumulada, a partir de sentimientos, emociones, estados de ánimos y vivencias. Esta es una vía de realización que entrelaza su implementación con elementos técnicos-formativos. Se emplearon métodos de investigación para el estudio teórico y metodológico con autores internacionales y nacionales con relación al tema en cuestión, que permitió asumir posiciones científicas, sustentados en los referentes sistematizados, como un aporte significativo que se revierta en la práctica, con pertinencia social y novedad científica, que lo hace relevante dentro del Modelo de formación del profesional del Nivel de Educación Superior de Ciclo Corto en Enfermería.
\end{abstract}

Canto coral, Formación integral, Enfermería

Citation: OSA-RICARDO, Arlena, JONES-SÁNCHEZ, Elisneisis, RODRÍGUEZ-JUAN, Arién and BARREIROS-LÓPEZ, Silvia Elisa. The choral song for the integral training of students in Nursing. Journal Educational Theory. 2021. 5-14: 10-20

\footnotetext{
* Correspondence to Author (e-mail: arlenaosa@gmail.com)

$\dagger$ Researcher contributing as first author.
} 


\section{Introduction}

Music is a universal artistic language, which has a great educational and communicative power; it has the possibility of being contagious and bringing people closer together, expanding their world of relationships. One of the most natural expressions of music is singing, which favors the development of aesthetic taste, knowledge, sensitivity, emotions, and feelings.

The human voice, as the first musical instrument and the most perfect, has its origin since ancient times. Throughout its evolution, man has communicated through various systems of codes. One of humanity's most successful and enduring legacies has been speech and singing. As language became richer and perfected, sung language emerged. Historically, singing is configured as a musical practice exercised and disseminated in different ethnicities and cultures.

Magical-religious ceremonies of the primitive communities, war contests of the ancient peoples, hunting rituals, propitiatory episodes of rain, among others; they were organized by a guide, priest, sorcerer or leader who received a response from the monodic collective (to one voice) or polyphonic (to several voices) and allowed to unify the collectivity, seed of choral singing, as an organized exercise of people who respond to a director.

Choral singing was present in the Middle Ages, in the Renaissance, in the Baroque and Classicism period (seventeenth and eighteenth centuries), during Romanticism (nineteenth century) and then twentieth century, faithful reflection of what was happening; it became a phenomenon of socialization, for the development of (solidarity and the formation of individuals. In the twenty-first century, creative and artistic potentialities are used and perfected as a process, through the instruction of contents of the theory and practice of choral singing.

Particularly in young people, choral singing is revealed as an attractive, enriching, and formative alternative that teaches to coexist, share, be disciplined and respect the other, by communicating experiential experiences; that is why it is significant in the movement of amateur artists, because it contributes positively to the integral formation of the personality, fundamentally at this stage of human development.
The choir is a representative institution within the universities of the world. Within the artistic-cultural universe of this educational level, it has been present, in one way or another, in the formative process. Choral singing is of special interest due to its characteristics, because it allows the integration and acquisition of values that make a group of students, ethically and aesthetically committed human beings, by incorporating the awareness of the individual and collective act. This is precisely one of the specific social commissions of this type of grouping, the teaching-research-extension relationship.

The University Extension has an essential role in the interrelation of the university with society, and in turn, integrates the presence of a formative process with the aim of promoting culture in the interuniversity and extra-university community. The National University Extension Program of the Ministry of Higher Education (MES), since March 2004, establishes the Guidelines for artistic-cultural activity in Cuban universities.

The University of Medical Sciences of Havana, with its networks of faculties, must demonstrate its relevance in this area, and be a promoter of universal values, mainly humanistic value, ethics, intercultural dialogue, mutual understanding and peace. As a substantive process, the University Extension, part of the link of the health-university-community system, coexisting the professional training of students within these scenarios.

This university, a trainer of health professionals, supports its projection towards culture intertwined with the content of human activity. The University Extension provides attention to the community, where it exerts a social impact on the training process.

One of the specialties that is studied at the University of Medical Sciences of Havana, is the Nursing of Higher Education Level of Short Cycle, where the specialty is carried out for 3 years, whose object of study is the care of the person, the family, the community and the environment.

In addition, it is responsible for diagnosing and treating in the area of its competences the individual and collective responses to the manifestations of the healthdisease process. 
It applies the logic of the nursing care process as a scientific method of the profession, considering actions of promotion, prevention, cure and rehabilitation to guarantee the physical, mental and social well-being of the human being. It also uses the teaching, administrative and research processes to obtain the quality and optimization of these services, in the search for excellence.

For the achievement of this purpose, choral singing can be a way for the integral formation of the student, and build the relationship of trust and cohesion with peers; singing in a group, consciously and unconsciously incorporates human values, appreciates harmony in order and discipline, both personal and collective, since to sing all together, you must go to the same rhythm, follow the guidelines of the director, tune and sing well, as well as know how to listen.

Based on the experience in choral singing, the student learns musical elements, through the technical-vocal exercises, the qualities of sound, vocal typology, the texts of the songs; coming to internalize knowledge about vocal education, to then be able to apply to other contexts and create from them. In addition, it develops the affectivevolitional sphere and enriches interpersonal relationships with ethics, as an important aspect.

When consulting different authors, who address issues related to choral singing in professional training, important studies have been revealed, which are reflected in master's and doctoral theses, scientific articles at the national and international level such as: Estrada, A.T and Hernández, M (2001); Castle, J. A (2008); Guerra, D \& Sánchez, P (2008); Rivas, M, Bastanzuri M.A, Olivera, M (2013); Alessandroni, N and Etcheverry, E (2013); Fernández, Y, Ramírez, C.Y and Briceño, J.M (2013); Duque, M.C (2015) and Narain, J (2016).

As a result of this exploratory stage, the fundamental shortcomings that led to the following scientific problem were reveralized: How does choral singing contribute to the integral formation of students of the Higher Education Level of Short Cycle in nursing? and the study of the theoretical-methodological references of choral singing in contribution to the integral formation of Nursing students is outlined as an objective.

\section{Development}

Singing is an activity of the human species, a natural means of expression common to all races. Its origins date back to prehistory, naturally to the fascination of the human being for rhythm, the emission of sounds to identify objects, phenomena and people. These very elementary sounds in their beginnings, would later form the inflections of language.

To express himself, primitive man performed singing as a means of communication, where he linked his activity to the rhythmic process, that is, by hitting one stone with another, by patting with joy for a good hunt or the arrival of rain, by drawing his living reality, as well as other ways of manifesting his primitive art or culture.

According to Hurtado, A. (2003), the emergence of music is related to singing, because man gave a characteristic stamp to his voice to stimulate the animals that accompanied him to his agricultural tasks or to help himself with rudimentary farming instruments. Thus appeared the songs of work, which exist and are used today in some countries. In periods such as the Paleolithic, Mesolithic and Neolithic, this type of singing was also used, and constitute the antecedents of what would later be called the choir.

According to Risquet,S, the word chorus comes from the Greek ronda. It also states that Greek choirs were formations of men, women, mixed, or men and boys who sang only monodic music (with one voice), usually in the theater (Risquet,S. 2012, p.8).

This author affirms that choral singing did not always mean a meeting of singers who made music collectively, because in Ancient Greece the term corresponded to the site intended for the dancers of tragedies and 11 comedies. Later the dance itself was called a choir and the number of singers who accompanied it also received that name (p.3).

The denomination of choir that is known today comes from the Middle Ages, a time when the Catholic Church stopped the fantasy of the creators of music conceived for collective singing, by establishing strong dogmas in this regard. 
García, I (1984), expresses that there were several typologies of this practice such as: choirs accompanied by dances in mythical ceremonies, collective, liturgical and congregational songs, multitudinous songs where customs of ethnic groups and peoples are manifested, as well as spontaneous songs performed by an audience from the initial impulse motivated by the solo singer (p. 45). Choral singing was used to worship their deities (gods). Also, in other cultures such as the Hindu, it was used to tell legends, about the creation of the world.

In Ancient Egypt, only men were allowed to sing, because music was regarded as the immediate hierarchy to the pharaoh and the main musicians of the royal palace orchestra were like relatives of the king. In Mesopotamia, it was intimately associated with rites of worship to the stars and gods, also women's choirs were organized, when they received the men who returned victorious from the war. In the Old Testament, the existence of organized choirs in Israel is documented. They were scholastic choirs with instrumental accompaniment whose repertoire was transmitted from generation to generation.

In the Middle Ages, a time when the Catholic Church stopped the fantasy of the creators of music conceived for collective singing, by establishing strong dogmas in this regard; but even so in this period the liturgical chant, derived from the East, is formalized: the Ambrosian chant, the Hispanic chant and the Gregorian chant; the first motets appear, and a primitive polyphony: the organum and the discanto. It is also in the Middle Ages, when he creates a musical notation that reaches our days and that allows us to build the choral repertoire.

In the Renaissance, new forms of choral singing appear, which exchange melodic themes with profane singing: masses, motets and other religious compositions. At the end of the Renaissance, the first(oratorios) appear, although there were precursors of the genre and works, long before the 1600s. Finally, the period provides the Protestant Choir.

At the beginning of the tenth century, in the period known as ancient Ars, polyphony appeared, which made possible the development of vocal groupings.
In the fourteenth and fifteenth centuries, in the period known as Ars nova, children become part of the choirs, In the sixteenth century, there is an increase in the number of members and the voices are named according to their tessitura (cantus, altus, tenor and basses). In the seventeenth and eighteenth centuries, in the periods called Baroque and Classicism, the choirs continue to increase the number of members and the voices that designate their tessitura are named with the current terms (soprano, contralto, among others).

In the twentieth and twenty-first century, choral singing continues to have an impact of socialization and fulfills functions inherent in the life of a people, both as a way for the expression of community feelings, and as resources of religious, political and even military utility. Agroup of singers who gather to perform a musical work. (Muñoz, A, M. 2008, p.122). Whereas, for the Colombian researcher Gallardo J. (2011), a choir is the set of people who simultaneously sing a piece of music (p. 69). Both definitions are similar and respond to the collective utility of a group of people.

The presence of the choir in Cuba dates from the early sixteenth century, however, there are very few references that have reached the present day. With the arrival in Cuba of the colonizers, with the Spanish and African migrations, they were forming a new culture with manifestations and practices of both roots. However, in the seventeenth century, musical practice acquired some importance, including choral, but always linked to the Cathedral of Santiago de Cuba and the Parroquial Mayor of Havana. In the eighteenth century, Cuban musical historiography always reserved a privileged space for Esteban Salas, who was the first important composer of choral music.

Throughout the nineteenth century and part of the following century, religious choral music was written, which begins to take boom within it, Italian opera and choral activity in Cuba. The program for the development of choral music in Cuba, expresses that choral singing is based on musical roots. From the third and fourth decade of the twentieth century, and in which the illustrious composer Alejandro García Caturla appears, pioneer in aspects of Cuban music and initiator of choral song. 
In 1919, the choir director and pedagogue María Muñoz de Quevedo arrived in Cuba from Spain. Graduated from the Santa Cecilia Conservatory of Cádiz, born in La Coruña in 1894, she received classes from the teacher Manuel de Falla. Since his arrival in Cuba, he realized the need to create new cultural institutions on the island that promoted national and universal music, so he developed this work. Itsgreatest achievement was the foundation in 1931, of the Choral Society of Havana, a group that had its debut on November 25 of the same year in the Teatro Principal de la Comedia.

After the disappearance of the Havana Choir, existing groups such as the National Choir, the University Choir of the East and the Philharmonic Choir, choral singing continued to spread in Cuba. With the revolutionary triumph, the rise of choirs as a fundamental element of work with the masses increased, for the rescue of forms and values of our identity. At the end of the twentieth century, work with amateurs was resumed, mainly the creation of children's songs. This work was followed by other musicians in the twenty-first century, throughout the country with excellent results.

According to EcuRed (2019), choral singing is an artistic manifestation of a collective nature, through which it is possible to develop the vocal technique (of singing) in the individual, its organization and distribution in a choir, as well as the assembly of different national and international works that are interpreted. It is done in a work in unison or by well-crafted strings (p. 2). Ingeneral, the artistic activity of the choir itself, its repertoire, assembly of voices and other musical elements, depends on a musician in charge of preparing and coordinating the different voices for the interpretation of the musical work, that musician, is the Director.

According to the composer, pedagogue and researcher Kodály, Z (1967), the best way to reach the musical aptitudes that we all possess is through the instrument most accessible to each of us, the human voice (In: Ponsoda, A. 2005, p. 71). Within the process of musicalization, the work of choral singing in the choirs is important. According to Gallardo (2011) by their disposition and participants, the choirs can be classified as follows: From white voices or children's choir, Male or female, Mixed male and female voices (p.143).
The musicality of the aspirant is an important factor for his admission into the choral group, which means being tuned and rhythmic. The musical ear as previously proposed, is closely linked to the development of the musical culture of each individual and is the starting point of any activity in this sphere of art.

In many cases, only the extent of the voice is considered and not its color. It is possible that the aspirant can reach high-pitched sounds, but without the characteristic timbre of tenor or soprano. For this condition, it should not be located in these strings, because then the quality of the choral sound that is intended to be achieved is threatened and the voice could be damaged, it is the selection of the repertoire as the basis of the content of the choral activity, since it carries the message that is transmitted to the viewer. Its planning depends on its characteristics and objectives; its raison d'être is closely linked to the organization of its life.

The repertoire must satisfy demands of a pedagogical-musical, technical, aesthetic, dramaturgical and above all social nature; this wide universe demands from the Director a continuous planning and a deep study of works that allows him to make a successful selection. He has the responsibility of ensuring the musical training of his singers, so that the works he selects must have a pedagogical character that forms in them aesthetic, ethical and moral values.

The first works should be easy, where the singers can experience the success of their work, with works that sound quickly, with a clear melody and not very long phrases for the breath toreach. For this stage, songs where the voices are melodic and are easily captured, without chromaticism, surprise modulations and rhythmic, metric or harmonic complications are appropriate; In addition, the work situation of the choir will be taken into account so that the voices are not damaged by an overload in the acute or low register. The text must be in correspondence with the intellectual level and age of the singers, as it must capture the meaning of the message to achieve an interpretation that convinces him and the public.

That is why, a choir that begins, integrated by singers who participate for the first time in the choral activity and have no training, it is recommended to start the work with songs in unison and accompaniment. 
Afterwards, they can perform canons of two or more parts, in preparation for the study of works in several voices. With the canon, the training of the harmonic ear and auditory independence begins.

This methodological order is not invariable, since the characteristics of the choir (vocal quality, musical quality, experience) indicate the strategy that must be followed in relation to the repertoire. The correct methodology of choral singing depends essentially on the ability of the Conductor to guide its members towards a homogeneous work, aimed at a truly achievable goal. In this way, it contributes not only to acquiring vocal faculties, but to benefiting the individual human values that serve him for his personal integrity.

In this sense, the occupational profile of the Senior Nurse of Short Cycle, declares that, with acquired skills, he will perform his care functions related to the attention to people who are tributaries of specific care in the Maternal and Child, Clinical Surgical and Intensive care and emerging areas. The specific nursing care will be manifested in the areas: Maternal and Child, Clinical Surgical and Intensive and Emerging Care according to the profile of the graduate. (MINSAP. 2018, p. 5)

Humanistic training is a mainstay in the career. Nursing stands out for its prominence for the impact of education at work for the development of professional and citizen morality and the subjects' physical education, English and psychology are added.

The Faculties of Nursing, as an educational and cultural institution, assume a marked responsibility with the formation of their human resources in society. Considering that the nursing student must put into practice, the exercise of their profession within the training process for their future performance, all this, with the acquisition of general and specific professional skills. It is then a question of achieving an integration between the positive qualities for a professional, which corresponds to the social commission.
Integral formation requires the harmonious development of all the processes that make up the educational institution, as well as the contents of the study plan, through a system of actions, aimed at the different spheres of personality. To achieve this and meet the demands of today's Cuban society, universities have the responsibility to graduate professionals capable of solving the complex problems they face. For the achievement of the integral formation of the students, it is necessary to incorporate contents related to different artistic manifestations, and choral singing as a form of collective musical expression, can contribute to develop knowledge, skills, habits, personal and social aspects in the students, which help, in the acquisition of a solid basic competence, manifested in the demands of the Model of the professional in nursing.

The pianist of Shola Cantorum from Venezuela, (Raga, A.M (2005) expressed: "Choral singing is therapeutic, it facilitates the identification of people, it allows them to accept themselves as they are by the magic of the union of many diverse people for a common good. Choral singing is a school of life." (In: Ecured. 2019, p. 3). This approach is assumed by the author of the research, since in nursing students, choral singing stimulates, has a mobilizing effect, allows the knowledge of socio-cultural roots and constitutes an ideal tool in the restoration of human balance, so that it is applicable for life; It is an accurate representation to use useful and creatively time, channel concerns and simultaneously realizes in the individual an ethical and aesthetic elevation, as well as the possibility of expressing through singing, feelings, emotions and perceptions of the world.

In addition to developing collectivism, responsibility, humanism, solidarity, patriotism, anti-imperialism, respect, honesty, honesty, modesty, simplicity, humility, self-denial, selflessness, the sense of equity, love of study and work, among other values that perfect the behavior of the individual and enhance the mode of action in the personality. Proof of this vision is expressed by the pedagogue Ponsoda, A L (2005) who proposed, that choral singing is very important for the pleasure that derives from the effort to achieve good collective music, providing disciplined men and women, and noble character, its value in this aspect is incalculable (p. 79). 
The above allows us to affirm that choral singing in the training of students in nursing, can provide the following benefits:

It helps build self-confidence, the level of personal well-being and cohesion with peers. It contributes to relate the techniques of singing with the contents of subjects of the career, can be applied in pre-professional practice and give an interdisciplinary character to its training. It favors the appropriation of communicative skills. Cooperation between the people who make up the choir. It consciously and unconsciously promotes values such as: affection for harmony, order, mutual respect, discipline both personal and collective responsibility, as well as companionship and solidarity.

You learn to respond to patterns such as; the rhythm, the guidelines of the Director, tune well and listen to the one next to you. This aspect guarantees for his profession, respect for his superiors, working under a balanced and equitable pace in line with his colleagues, as well as paying good auditory attention to the command voice, which, in this case, it is the doctor who indicates what he should do.

It educates the control of breathing, the regulation of relaxation or tension of the vocal cords, an adequate resonance, the emission and the correct pronunciation of sounds. It produces an interaction between different lived experiences, spending time together creates an enriching and natural relationship in the improvement of the human condition within society. Improves concentration and memory. Develops aesthetic values. It generates cognitive operations: attention, concentration, analysis and interpretation, which allows you to know and manage your body in the face of an immediate response.

García, I (2002), identified five aspects of socio-psychological well-being related to the contributions of choral singing for people, which are fully assumed in this research, they are the following:

Positive relationships: The choir facilitates interpersonal relationships. Mastery of the environment: choosing and identifying with a choral group satisfies communication, expression and/or enrichment needs. Purpose in life: The choir exists from collective goals.
Personal growth: Choirs enhance personal enrichment by creating skills related to both artistic and extra-artistic practices. Integration: they integrate the singer to the micro society that creates each group and to the general society that serves as a real or ideal reference as environments of musical formation and structures of dynamization of the sociocultural environment (p. 64).

The nurse has to perform, for choral singing, relaxation, breathing and vocalization exercises, know their vocal possibilities, be aware of the physiological processes in singing (resonance, breathing, emission and support of sound), try to emit an even and balanced sound since they are singing collectively, in the search for safety and expressiveness when singing, taking into account the knowledge of the proper use and care of the voice and the organs involved. All this allows you to have a clear, fluid, coherent and efficient communication.

In the attitudinal and the relationship with others, choral singing offers nursing students resources to express themselves in a socially acceptable way, allows them to assume responses in front of the group, which helps them to issue criteria and react to an immediate response, increases social interaction and verbal and non-verbal communication, accesses cooperation and challenge, provides training and recreation of the general therapeutic environment, where you must use therapeutic communication, which aims to help the patient, family member or community, and in turn to work together to solve their problems.

In addition, understanding and considering, in addition to their knowledge, a clear language that attracts the patient to remain calm in the specific situation they encounter, provides bedside care and direct care to patients in the hospital and consultations with doctors and other members of the health care team, on the most suitable care plan. On the cognitiveaffective plane are assumed in this research, the psychological criteria and presuppositions of Vygotsky, LS when expressed, thought and language turn out to be the key to understanding the nature of human consciousness (1982, p.361). In addition, the student experiences his selfesteem, byvarying his skills. 
As for the affective, it allows you to act more confident in yourself, be more cheerful, independent, accept challenges and by recognizing your personal value, you can be more tolerant of your limitations; Consequently, this student is able to manifest human values such as: thinking about others, the capacity for empathy, understanding and tolerance, cultivating patience, cooperative sense, solidarity, love for music, sensitivity, discovering and experiencing the cause-effect relationship of effort, organization at work, enjoying the result, after an effort or experiencing the aesthetic character of choral singing.

Another important element is social selfesteem. The student of Nursing, when practicing choral singing, feels that he develops his abilities, which allows him to take advantage of his potentialities more depending on the subjects of his career, he is more persevering before some projected result, he strives and assumes positive expectations, which serve him for his professional performance.

For all the above, it is considered that choral singing can contribute to ethics, that it feels like a competent individual, capable of fulfilling its commitments, assumes responsibilities, respects human values and is perceived with more virtues than defects. Individual and collective stimulation plays a fundamental role in the process of applying choral singing in the integral formation of students in Nursing.

The Faculty of Nursing is one of the ideal spaces for the use in students of tools and resources to stimulate their creativity and artistic development, which allows them to promote their experience, expressive sensitivity and at the same time, expand their culture.

To fulfill these purposes, the selection and adaptation of the works to be used in choral singing is important, in addition to what is related to the interpretation that includes tuning, rhythm, vocal technique, nuance, diction, text, intonation and sound quality; encourage participation in cultural, political and festival activities, both inside and outside the center. All this also contributes to the integral formation of the student.
Therefore, despite the differences and complexities in the contents of choral singing and the study of nursing, they complement each other, and their link is positive and advantageous, enabling students to be responsible human beings in the mission and projected towards the future, for the benefit and fulfillment of the demands required by a public health professional in Cuba.

\section{Conclusions}

The assessment of the theoretical references of Choral Singing, had as a starting point in a general way, the historical background and the benefits it provides in the integral formation of the students of the Level of Education of Short Cycle in Nursing. Theoretical-methodological considerations of Choral Singing were deployed for the usefulness and development of vocal and educational skills, which strengthens in a positive way, not only musical skills, but the personal qualities of students in Nursing. The analysis of the referential theoretical framework allowed an approach to the reality and timeliness of the subject, its particularities in Cuba and in the context of comprehensive training in Nursing, which made possible conceptual positions established by Sánchez P (2003) and Col (2006), by constituting the premises in the benefit and importance of Choral Singing for the integral formation of students, timely aspect due to its relevance in this training scenario.

\section{Referencias}

Addine, F. (1998). Relación sistémica entre los componentes del proceso de enseñanzaaprendizaje. La Habana, Cuba: Editorial Pueblo y Educación.

Álvarez, C. (1996). La pedagogía universitaria. Una experiencia cubana. Ponencia presentada en Pedagogía 95. La Habana, Cuba.

Estévez, P. R. (2004). El ideal de la formación cultural integral. La Revolución estética en la educación. La Habana, Cuba: Editorial Pueblo y Educación.

Estrada, A. T., \& Hernández, M. (2001). Cultura en la enfermería comunitaria. Revista Humanidades Médicas, 1(3). Obtenido de http://scielo.sld.cu/scielo.php?script=sci_arttext \&pid=S1727-81202001000300005 
García, I. (1984). Tradición y caminos del arte coral en Cuba. Trabajo de Diploma, Instituto Superior de Arte, La Habana.

Hemsy, V. (enero-junio de 2004). La Educación Musical en el siglo XX. (C. Guerra, Ed.) Revista Musical Chilena, 58(201), 74-81. Obtenido de https://revistamusicalchilena.uchile.cl/index.ph $\mathrm{p} / \mathrm{RMCH} /$ issue/view/1172

Méndez, J. A. (2003). Dirección Coral: Metodología y Práctica. La Habana, Cuba: Editorail Adagio.

Modelo de formación del profesional del Nivel de Educación Superior de Ciclo Corto. Técnico Superior en Enfermería. (2018). La Habana, Cuba.

Sánchez, P., \& Guerra, D. (1982). Canto. La Habana, Cuba: Editorial Pueblo y Educación. 